\title{
PENDIDIKAN DITINJAU DARI ASPEK FILOSOFIS
}

\author{
Fatkhul Mubin \\ fatkhulmubin90@gmail.com
}

PENDAHULUAN

\section{A. LATAR BELAKANG}

Filsafat merupakan ilmu yang sudah sangat tua. Bila kita membicarakan filsafat maka pandangan kita akan tertuju jauh ke masa lampau di zaman Yunani Kuno. Pada masa itu semua ilmu dinamakan filsafat. Dari Yunanilah kata "filsafat" ini berasal, yaitu dari kata "philos" dan "sophia". "Philos" artinya cinta yang sangat mendalam dan "sophia" artinya kebijakan atau kearifan. Istilah filsafat sering dipergunakan secara populer dalam kehidupan sehari-hari, baik secara sadar maupun tidak sadar. Dalam penggunaan populer, filsafat dapat diartikan sebagai suatu pendirian hidup (individu) dan dapat juga disebut sebagai pandangan masyarakat (masyarakat). Mungkin anda pernah bertemu dengan seseorang dan mengatakan: "filsafat hidup saya adalah hidup seperti oksigen, menghidupi orang lain dan diri saya sendiri". Orang lain lagi mengatakan: "Hidup harus bermanfaat bagi orang lain dan dunia". Hal ini adalah contoh sederhana tentang filsafat seseorang. Selain itu, masyarakat juga mempunyai filsafat yang bersifat kelompok. Oleh karena manusia itu makhluk sosial, maka dalam hidupnya ia akan hidup bermasyarakat dengan berpedoman pada nilai-nilai hidup yang diyakini bersama. Hal ini yang disebut filsafat atau pandangan hidup. ${ }^{1}$

Berpijak pada beberapa definisi tentang filsafat ilmu itu maka kemudian dapat dibuat aplikasi pengertian filsafat ilmu dalam bidang pendidikan, yang dapat disebut dengan istilah filsafat ilmu pendidikan. Filsafat ilmu pendidikan adalah filsafat, khususnya adalah cabang dari filsafat pengetahuan, aliran-aliran utamnya dan teori utama belajar, yang secara mendalam, spekulatif, dan komprehensif mempelajari tentang hakekat ilmu pendidikan. ${ }^{2}$

$$
1
$$

${ }^{1}$ Rukuyati dan andriani, Mengenal Filsafat Pendidikan, Draf Buku Universitas Negri Yogyakarta, hal. 
Apabila dilihat secara lebih mendalam, yaitu karena filsafat ilmu pendidikan termasuk cabang dari filsafat maka dapat dikemukakan bahwa dasar-dasar berpikir dalam melakukan perenungan filsafat ilmu pendidikan harus mengacu pada dasar-dasar filsafat yang utama, yaitu dasar metafisika (ontologi), dasar epistemologi, dan dasar aksiologi. Filsafat akan menentukan "mau dibawa kemana" siswa kita. Filsafat merupakan perangkat nilai-nilai yang melandasi dan membimbing ke arah pencapaian tujuan pendidikan. Oleh sebab itu, filsafat yang dianut oleh suatu bangsa atau kelompok masyarakat tertentu atau yang dianut oleh perorangan (dalam hal ini Dosen/Guru) akan sangat mempengaruhi tujuan pendidikan yang ingin dicapai. ${ }^{3}$

Dalam proses pendidikan cabang filsafat, aliran utama filsafat serta aliran utama filsafat pendidikan menghendaki agar peserta didik dapat menggunakan kemampuannya secara konstruktif dan komprehensif untuk menyesuaikan diri dengan tuntutan perkembangan ilmu dan teknologi. peserta didik harus aktif mengembangkan pengetahuan, bukan hanya menunggu arahan dan petunjuk dari guru atau sesama siswa. Kreativitas dan keaktifan peserta didik membantu untuk berdiri sendiri dalam kehidupan, aliran-aliran filsafat ini mengutamakan peran peserta didik dalam berinisiatif dan juga mengembangkan potensinya.

Dalam cabang-cabang filsafat serta aliran utama filsafat dan aliran utama filsafat pendidikan memiliki prespektifnya masing-masing dalam pendidikan.Berdasarkan uraian di atas, penulis merumuskan masalah mengenai prespektif Filosofis dalam pendidikan dari Cabang-cabang filsafat, aliran utama filsafat, aliran utama filsafat pendidikan seta teori belajar utama.

\section{B. RUMUSAN MASALAH}

1. Bagaimana Perspektif Filosofis dalam pendidikan dari cabang-cabang filsafat ?

Saihu, S. (2019). Pendidikan Pluralisme Agama: Kajian tentang Integrasi Budaya dan Agama dalam Menyelesaikan Konflik Sosial Kontemporer. Jurnal Indo-Islamika, 9(1), 67-90,

Saihu, S. (2019). IMPLEMENTASI MANAJEMEN BALANCED SCORECARD DI PONDOK PESANTREN JAM'IYYAH ISLAMIYYAH TANGERANG SELATAN. Mumtaz: Jurnal Studi Al-Quran dan Keislaman, 3(1), 1-22.

Saihu, S. (2019). KOMUNIKASI PENDIDIK TERHADAP ANAK BERKEBUTUHAN KHUSUS DI SEKOLAH KHUSUS ASY-SYIFA LARANGAN. Andragogi: Jurnal Pendidikan Islam dan Manajemen Pendidikan Islam, 1(3), 418-440.

Saihu, S., \& Marsiti, M. (2019). PENDIDIKAN KARAKTER DALAM UPAYA MENANGKAL RADIKALISME DI SMA NEGERI 3 KOTA DEPOK, JAWA BARAT. Andragogi: Jurnal Pendidikan Islam dan Manajemen Pendidikan Islam, 1(1), 23-54.

${ }^{3}$ Muhammad Kristiawan, Filsafat Pendidikan, The Choice Is Yours, (Yogyakarta : Valia Pustaka : 2016) hal. 6 
2. Bagaimana Perspektif Filosofis dalam pendidikan dari aliran utama filsafat ?

3. Bagaimana Perspektif Filosofis dalam pendidikan dari aliran utama filsafat pendidikan?

4. Bagaimana Perspektif Filosofis dalam teori belajar utama?

\section{TUJUAN PEMBAHASAN}

1. Untuk mengetahui bagaimana Perspektif Filosofis dalam pendidikan dari cabang-cabang filsafat, aliran utama filsafat, aliran utama filsafat pendidikan dan teori belajar utama.

\section{PEMBAHASAN}

\section{A. PRESPEKTIF FILOSIFIS DALAM PENDIDIKAN DARI CABANG-CABANG} FILSAFAT

\section{Ontologi}

Berbicara tentang ontologi tentu kita tidak akan bisa melepaskan diri dari kajian filsafat hal ini lebih kepada adanya keterkaitan istilah ontologi dengan filsafat. Secara etimologi kata ontologi berasal dari bahasa Yunani sebagaimana sebagaimana Adib, dalam konteks ini dapat kita pahami bahwa ontologi berasal dari kata ontos dan logos. Ontos memiliki makna suatu wujud sedangkan makna logos berarti ilmu. ${ }^{4}$

Secara terminologi ontologi adalah "cabang ilmu filsafat yang berhubungan dengan hakikat hidup. ${ }^{5}$ Jadi ontologi adalah satu kajian keilmuan yang berperpusat pada pembahasan tentang hakikat. Tokoh Yunani yang memiliki pandangan yang bersifat ontologis, seperti Thales, Plato, dan Aristoteles.

Cara memperoleh pengetahuan, filosof mulai menghadapi objek objeknya untuk memperoleh pengetahuan. Objek objek itu difikirkan secara mendalam sampai pada

${ }^{4}$ Mohammad Adib, Filsafat Ilmu: Ontologi, Epistemologi, Aksiologi, dan Logika Ilmu Pengetahuan (Yogyakarta: Pustaka Pelajar, 2011), 69.

${ }^{5}$ KBBI-Kamus Besar Bahasa Indonesia-digital 
hakikatnya. Inilah sebabnya dinamakan Teori Hakikat. Ada yang menamakan bagian ini Ontologi. ${ }^{6}$

Sedangkan objek kajian ontologi meliputi, ada individu, ada umum, ada terbatas, ada tidak terbatas, ada universal, ada mutlak-Tuhan Yang Maha Esa. Istilah ontologi ini lebih banyak digunakan ketika membahas yang ada dalam konteks filsafat. ${ }^{7}$ Dari apa yang telah dipaparkan di atas dapat dipahami bahwa ontologi adalah hakikat tentang keberadaan yang meliputi keberadaan segala sesuatu yang ada dan yang mungkin ada. Untuk lebih jelasnya mengenai konsep ontologi di sini adalah upaya untuk membahas tentang pendidikan.

Pendidikan adalah suatu kegiatan yang sadar akan tujuan. Adanya pendidikan bermaksud untuk mencapai tujuan, maka ini menjadi ini tujuan menjadi hal penting dalam penyelenggaraan pendidikan. Secara umum dapat dikatakan bahwa pendidikan dapat membawa anak menuju kepada kedewasaan, dewasa bagi jasmani dan rohani. ${ }^{8}$

Pengertian pendidikan di pandang sebagai sesuatu yang sulit untuk di definisikan, hal itu dikarenakan banyaknya definisi pendidikan yang dikemukakan oleh berbagai ahli pendidikan. Akan tetapi dalam konteks ini sesulit apa pun mendefinisikannya sebagaimana Ahmad Tafsir masih dalam Toto pendidikan Islam harus tetap di definisikan karena pendidikan Islam itu sendiri berkaitan langsung dengan kajian ilmiah untuk itulah dalam hal ini pendidikan Islam tetap harus di definisikan. Sebenarnya ontologi dalam kajian ini lebih menekankan pada aspek hakikat keberadaan, yang dimaksud keberadaan di sini adalah keberadaan pendidikan. Sedangkan hakikat pendidikan berkaitan dengan hakikat manusia. ${ }^{9}$ Dalam konteks ini yang berusaha di sentuh oleh ontologi pendidikan adalah mencoba mencari hakikat pendidikan dan hakikat manusia. Dari pemahaman tersebut, sudah tentu

${ }^{6}$ Ahmad Tafsir, Filsafat Umum (Bandung : Rosda 2016 ) H. 28

7 A. Susanto, Filsafat Ilmu: Suatu Kajian dalam Dimensi Ontologi, Epistemologis, dan Aksiologis (Jakarta: Bumi Aksara, 2011), 91.

8 Saihu, S. (2019). KONSEP MANUSIA DAN IMPLEMENTASINYA DALAM PERUMUSAN TUJUAN PENDIDIKAN ISLAM MENURUT MURTADHA MUTHAHHARI. Andragogi: Jurnal Pendidikan Islam dan Manajemen Pendidikan Islam, 1(2), 197-217.

Saihu, S., \& Rohman, B. (2019). PEMBENTUKAN KARAKTER MELALUI MODEL PENDIDIKAN TRANSFROMATIFE LEARNING PADA SANTRI DI PONDOK PESANTREN NURUL IKHLAS BALI. Edukasi Islami: Jurnal Pendidikan Islam, 8(02), 435-452.

Saihu, S., \& Taufik, T. (2019). PERLINDUNGAN HUKUM BAGI GURU. Al Amin: Jurnal Kajian Ilmu dan Budaya Islam, 2(2), 105-116.

Saihu, S. (2020). KONSEP PEMBAHARUAN PENDIDIKAN ISLAM MENURUT FAZLURRAHMAN. Andragogi: Jurnal Pendidikan Islam dan Manajemen Pendidikan Islam, 2(1), 82-95.

Saihu, S. (2020). ETIKA MENUNTUT ILMU MENURUT KITAB TA'LIM MUTA'ALIM. Al Amin: Jurnal Kajian Ilmu dan Budaya Islam, 3(1), 99-112.

Saihu, Aziz, A., Mubin, F., \& Sarnoto, A. Z. (2020). Design of islamic education based on local wisdom (An analysis of social learning theories in forming character through ngejot tradition in bali). International Journal of Advanced Science and Technology, 29(6), 1278-1293.

${ }^{9}$ Anas Salahuddin, Filsafat Pendidikan (Bandung: Pustaka Setia, 2011), 129. 
hakikat pendidikan atau ontologi pendidikan berakar dari kebutuhan hidup manusia berkenaan dengan proses berpikir, berkemandirian dalam berbagai macam hal baik dalam kemandirian berpikir. ${ }^{10}$

Pendidikan ditujukan untuk membawa manusia mengenal hakikat segala sesuatu, baik itu alam, dirinya dan Tuhan. Dalam kerangka pendidikan Islam maka hakikatnya lebih diarahkan untuk mengenal hakikat alam, dirinya, dan Tuhannya.

\section{Epistimologi}

Epistemologi berasal dari Bahasa Yunani yaitu episteme $=$ pengetahuan dan logos $=$ teori. Epistemologi dapat didefinisikansebagai cabang filsafat yang mempelajari asal mula atau sumber,struktur, dan metode yang sah tentang pengetahuan. Pertanyaandalam epistemologi adalah "apa yang dapat saya ketahui?" (TimDosen Filsafat Ilmu UGM: 32). Persoalan-persoalan dalam epistemologi adalah: bagaimanamanusia dapat mengetahui sesuatu?; Dari mana pengetahuan itu diperoleh?; Bagaimana validitas pengetahuan itu dapat dinilai?.

Dengan kata lain epistimologi membebicarakan pengetahuan dan bagaimana cara memperoleh pengetahuan.epistimologi petamakali muncul dan digunakan oleh J.F. Ferrier pada tahun $1854 .^{11}$

Epistemologi membicarakan pengetahuan dan susunannya. Ilmu atau science adalah pengetahuan-pengetahuan yang gejalanya dapat diamati berulang-ulang melalui eksperimen sehingga dapat dipelajari oleh orang yang berbeda dalam waktu yang berbeda. Epistemologi membahas hakikat ketepatan susunan berpikir yang secara tepat pula digunakan untuk masalah-masalah yang bersangkutan dengan maksud menemukan kebenaran isi pernyataannya. Isi pernyataannya adalah sesuatu yang ingin diketahui. ${ }^{12}$

\footnotetext{
${ }^{10}$ Ibid., 130.

${ }^{11}$ Ahmad Tafsir, Filsafat Umum (Bandung : Rosda 2016 ) H. 23

12 Ronaldo, R., Zulfikar, A., Saihu, Ismail, \& Wekke, I. S. (2020). International relations of the asia pacific in the age of trump. Journal of Environmental Treatment Techniques, 8(1), 244-246.

Saihu, M. M., \& Aziz, A. (2020). Implementasi Metode Pendidikan Pluralisme Dalam Mata Pelajaran Pendidikan Agama Islam. Belajea; Jurnal Pendidikan Islam, 5(1), 131-150.

Saihu, M. (2019). Urgensi 'Urf dalam Tradisi Male dan Relevansinya dalam Dakwah Islam di JembranaBali. Jurnal Bimas Islam, 12(1), 173-201.

Saihu, S. (2020). The Effect of Using Talking Stick Learning Model on Student Learning Outcomes in Islamic Primary School of Jamiatul Khair, Ciledug Tangerang. Tarbawi: Jurnal Keilmuan Manajemen Pendidikan, 6(01), 61-68.

Saihu, S. (2020). Pendidikan sosial yang terkandung dalam Surat At-Taubah Ayat 71-72. Edukasi Islami: Jurnal Pendidikan Islam, 9(01), 127-148.
} 
Pendidikan dapat diartikan dengan kegiatan mengubah manusia sehingga mengembangkan hakikat kemanusiaan. Kegiatan pendidikan dilakukan dari oleh dan untuk manusia yang bertujuan mengembangkan potensi kemanusiaan. Langeveld (seorang Paedagog Belanda) mengemukakan hasil analisis epistemologis dengan metode fenomenologis bahwa manusia adalah animal educandum, educabile dan educans. Analisis fenomenologis tentang manusia sebagai sasaran tindak mendidik ini menegakkan paedagogik (ilmu pendidikan) sebagai disiplin ilmu pengetahuan yang patut dipertimbangkan.

Pengetahuan manusia itu diperoleh dengan berbagai cara dan alat untuk memperolehnya. Adapun aliran yang berbicara tentang masalah ini atau masalah cara memperoleh pengetahuan adalah aliran empirisme, rasionalisme, positivisme, dan intuisionisme. ${ }^{13}$ Dari semua jenis pengetahuan di atas maka dalam ranah inilah epistemologi sebagai suatu alat untuk mengukur kebenaran tersebut.

Epistemologi memberikan sumbangan bagi filsafat pendidikan. Prespektif Epistimologi dalam pendidikan terletak pada Pengetahuan apa yang harus diberikan pada siswa, bagaimana cara memperoleh pengetahuan serta bagaimana cara menyampaikan pengetahuan merupakan sumbangan epistemologi dalam pendidikan. ${ }^{14}$

Epistemologi diperlukan dalam menyusun kurikulum. Kurikulum lazimnya diartikan sebagai sarana untuk mencapai tujuan pendidikan, dapat diumpamakan sebagai jalan raya yang perlu dilewati siswa dalam usahanya mengenal dan memahami pengetahuan. Agar mereka berhasil dalam mencapai tujuan, perlu diperkenalkan sedikit demi sedikit tentang hakikat pengetahuan (Barnadib, 1990: 21).

\section{Aksiologi}

Aksiologi berasal dari istilah Yunani yaitu; axios yang berarti sesuai atau wajar. Sedangkan logos berari ilmu, akan tetapi aksiologi juga dapat disebut juga dengan teori nilai. Aksiologi merupakan cabang filsafat ilmu yang membicarakan tentang tujuan ilmu pengetahuan itu sendiri dan bagaimana manusia menggunakan ilmu tersebut. Dalam hal ini yang ingin dicapai oleh aksiologi adalah hakikat dan manfaat yang terdapat dalam suatu pengetahuan. Jadi aksiologi di sini adalah menyangkut masalah nilai kegunaan ilmu. Dewasa ini, istilah axios $=$ nilai dan $\operatorname{logos}=$ teori istilah ini sebenarnya lebih akrab dipakai dalam

Aziz, A., \& Saihu, S. (2019). Interpretasi Humanistik Kebahasaan: Upaya Kontekstualisasi Kaidah Bahasa Arab. Arabiyatuna: Jurnal Bahasa Arab, 3(2), 299-214

${ }^{13}$ Ibid., 23-26

${ }^{14}$ Muhammad Kristiawan, Filsafat Pendidikan, The Choice Is Yours, (Yogyakarta : Valia Pustaka : 2016) hal. 14 
istilah filosofi. ${ }^{15}$ Menurut Scheller ada dua bidang yang paling populer terkait penilaian yaitu tingkah laku dan keadaan atau tampilan fisik, sehingga aksiologi dibagi dalam 2 jenis yaitu etik dan estetika. ${ }^{16}$ Adapun aksiologi dalam Kamus Besar Bahasa Indonesia aksiologi adalah kegunaan ilmu pengetahuan bagi kehidupan manusia; atau kajian tentang nilai, khususnya etika. ${ }^{17}$

Etika dapat membantu guru dalam cara-cara berpikir menghadapi permasalahanpermasalahan sulit untuk menentukan tindakan yang benar. Sedangkan estetika membantu guru meningkatkan keefektifan pembelajaran. Pada dasarnya pembelajaran dapat dipandang sebagai suatu bentuk ekspresi artistik, dan dapat dinilai menurut standar-standar artistik dari keindahan dan kualitas (Parkay, 1984 dalam Sadullah, 2007: 89-90). Berkenaan dengan ini guru adalah seniman dan secara terus menerus berusaha meningkatkan kualitas kerjanya.

Aksiologi merupakan cabang filsafat yang membahas nilai baik dan buruk serta indah dan jelek. Nilai terkait erat dengan pendidikan. Nilai selalu menjadi pertimbangan dalam merumuskan tujuan pendidikan. Perumusan tujuanpendidikan tanpa mempertimbangkan nilai-nilai adalah hampa. Selain itu, pendidikan sebagai fenomena kehidupan sosial, kultural dan keagamaan tidak dapat lepas dari system nilai (Barnadib, 1990: 21).

Implikasi aksiologi dalam dunia pendidikan adalah menguji dan mengintegrasikan nilai dalam kehidupan manusia dan menanamkan sikap dalam kepribadian peserta didik. Memang untuk menjelaskan apakah yang baik itu, benar, buruk dan jahat bukanlah sesuatu yang mudah. Apalagi, baik, benar, indah dan buruk, dalam arti mendalam dimaksudkan untuk membina kepribadian ideal anak, jelas merupakan tugas utama pendidikan. Pendidikan harus memberikan pemahaman atau pengertian baik, benar, bagus, buruk dan sejenisnya kepada

\footnotetext{
${ }^{15}$ Tim Penyusun, Pengantar Filsafat (Surabaya: IAIN Sunan Ampel Press, 2011), 92-93.

${ }_{16}$ Muhammad Kristiawan, Filsafat Pendidikan, The Choice Is Yours, (Yogyakarta : Valia Pustaka : 2016) hal. 51

${ }^{17}$ Saihu, S. (2019). PENDIDIKAN KARAKTER BERBASIS KEARIFAN LOKAL (STUDI DI JEMBRANA BALI). Edukasi Islami: Jurnal Pendidikan Islam, 8(01), 69-90.

Şahin, C. RELIGIA.

Saihu, S., \& Mailana, A. (2019). Teori pendidikan behavioristik pembentukan karakter masyarakat muslim dalam tradisi Ngejot di Bali. Ta'dibuna: Jurnal Pendidikan Islam, 8(2), 163-176.

Mubin, F. KEADILAN DALAM GENDER: KAJIAN KEPEMIMPINAN WANITA DALAM ISLAM1,

Saihu, M. (2019). Merawat Pluralisme Merawat Indonesia (Potret Pendidikan Pluralisme Agama Di JembranaBali). Deepublish.

Mubin, F. (2019). TAFSIR EMANSIPATORIS: PEMBUMIAN METODOLOGI TAFSIR PEMBEBASAN. Mumtaz: Jurnal Studi Al-Quran dan Keislaman, 3(1), 131-151. Mubin, F. MODEL-MODEL PEMBELAJARAN BERBASIS MADRASAH DAN KEGIATAN LAIN YANG DIPERLUKAN DI DALAMNYA (FAKTOR PENDUKUNGNYA).
} 
peserta didik secara komprehensif dalam arti dilihat dari segi etika, estetika dan nilai sosial. Dalam masyarakat, nilai-nilai itu terintegrasi dan saling berinteraksi. ${ }^{18}$

\section{B. PRESPEKTIF FILOSIFIS DALAM PENDIDIKAN DARI ALIRAN UTAMA FILSAFAT}

\section{Idealisme}

Idealisme berasal dari kata "Ideal," yaitu suatu yang hadir dalam jiwa. Aliran ini beranggapan bahwa hakikat kenyataan yang beraneka ragam itu semua berasal dari ruh (sukma) atau sejenis dengannya, yaitu sesuatu yang tidak terbentuk dan menempati ruang. Materi atau zat ini hanyalah suatu jenis dari penjelmaan ruhani. ${ }^{19}$

Idealisme adalah tradisi pemikiran filsafat yang berpandangan bahwa doktrin tentang realitas eksternal tidak dapat dipahami secara terpisah dari kesadaran manusia. Dengan kata lain kategori dan gagasan eksis di dalam ruang kesadaran manusia terlebih dahulu sebelum adanya pengalamanpengalaman inderawi.

Pandangan Plato bahwa semua konsep eksis terpisah dari entitas materinya, hal ini dapat dikatakan sebagai sumber dari pandangan idealisme radikal. Karya dan pandangan Plato memberikan garis demarkasi yang jelas antara pikiran-pikiran idealis dengan pandangan materialis. Sumbangan idealisme terhadap ilmu pengetahuan modern sangatlah jelas. Ilmu pengetahuan modern diniscayakan oleh kohesi antara bukti-bukti empiris dan formasi teori. Kaum materialis mendasarkan pemikirannya pada bukti-bukti empiris, sedangkan kaum idealis pada formasi teori. ${ }^{20}$

Dalam hubungannya dengan pendidikan, idealisme memberikan sumbangan yang besar terhadap teori perkembangan pendidikan, khususnya filsafat pendidikan. Filsafat idealisme diturunkan dari filsafat metafisik yang menekankan pertumbuhan rohani. Kaum idealis percaya bahwa anak merupakan bagian dari alam spiritual, yang memiliki pembawaan spiritual sesuai potensialitasnya. Oleh karena itu, pendidikan harus mengajarkan hubungan antara anak dengan bagian alam spiritual. Pendidikan harus menekankan kesesuian batin antara anak dan alam semesta. Pendidikan merupakan pertumbuhan ke arah tujuan pribadi

\footnotetext{
${ }^{18}$ Mahfud, MENGENAL ONTOLOGI, EPISTEMOLOGI, AKSIOLOGI DALAM PENDIDIKAN ISLAM
} (STAI : Hasan Jufri Bawean) hal. 2016) hal. 147

${ }^{19}$ Muhammad Kristiawan, Filsafat Pendidikan, The Choice Is Yours, (Yogyakarta : Valia Pustaka : ${ }^{20}$ Ibid., 157 
manusia yang ideal. Pendidik yang idealisme mewujudkan sedapat mungkin watak yang terbaik. Pendidik harus memandang anak sebagai tujuan, bukan sebagai alat. ${ }^{21}$

Filsafat idealisme pada abad ke-19 secara khusus mengajarkan tentang kebudayaan manusia dan lembaga kemanusiaan sebagai ekspresi realitas spiritual. Bagi aliran idealisme, anak didik merupakan seorang pribadi tersendiri, sebagai makhluk spiritual. Mereka yang menganut paham idealisme senantiasa memperlihatkan bahwa apa yang mereka lakukan merupakan ekspresi dari keyakinannya, sebagai pusat utama pengalaman pribadinya sebagai makhluk spiritual.

\section{Realisme}

Realisme ialah aliran yang berpendirian bahwa pengetahuan manusia itu ialah gambaran yang baik dan tepat dari pada kebenaran, dalam pengetahuan pengetahuan yang baik tergambarkan kebenaran seperti sesungguhnya ada. ${ }^{22}$ Dalam bidang pendidikan aliran realism berfokus pada tujuan pendidikan untuk membina kemampuan manusia melakukan interaksi yang konstruktif dalam hubungan manusia sebagai warga masyarakat dan melakukan penyesuaian diri dengan mengelola tanpa terlalu mengekploitasi alam. Pendidikan harus dilakukan dengan cara cara membantu siswa dan anak untuk memamhami dan menerima hukum hokum alam dan kehidupan apa adanya karena hokum kuhum menekan manusia sebagai hokum alam. ${ }^{23}$

Pendidikan dalam realisme memiliki keterkaitan erat dengan pandangan john locke bahwa akal-pikiran jiwa manusia tidak lain adalah tabularasa, ruang kosong tak ubahnya kertas putih kemudian menerima impresi dari lingkungan. Oleh karena itu, pendidikan dipandang dibutuhkan karena untuk membentuk setiap individu agar mereka menjadi sesuai dengan apa yang dipandang baik. Dengan demikian, pendidikan dalam realisme kerap diidentikkan sebagai sebagi upaya pelaksanaan psikologi behaviorisme ke dalam ruang pengajaran.

Murid adalah sosok yang mengalami inferiorisasi secara berlebih sebab ia dipandang sama sekali tidak mengetahui apapun kecuali apa-apa yang telah pendidikan berikan. Di sini dalam pengajaran setiap siswa akan subjek didik tak berbeda dengan robot. Ia mesti tunduk

\footnotetext{
${ }^{21} \mathrm{http}$ ///kuliah-e-learning.blogspot.com/2013/11/filsafat-idealisme-dalam-pendidikan.html

${ }^{22}$ Endang Saefunddin, Ilmu Filsafat Agama, (Imtima : 2007) hal. 22

${ }^{23}$ Ibid 97
} 
dan takluk sepatuh-patunya untuk diprogram dan mengerti materi-materi yang telah ditetapkan sedemikian rupa. ${ }^{24}$

Pada ujung pendidikan, realisme memiliki proyeksi ketika manusia akan dibentuk untuk hidup dalam nilai-nilai yang telah menjadi common sense sehingga mereka mampu beradaptasi dengan lingkungan-lingkungan yang ada. Sisi buruk pendidikan model ini kemudian cenderung lebih banyak dikendalikan skeptisisme positivistik, ketika mereka dalam hal apa pun akan meminta bukti dalam bentuk-bentuk yang bisa didemonstrasikan secara indrawi.

Pendidikan yang didasari oleh realisme bertujuan agar peserta didik menjadi manusia bijaksana secara intelektual yang dapat memiliki hubungan serasi dengan lingkungan fisik maupun sosial. Implikasi pandangan realisme adalah sebagai berikut:

a) Tujuan pendidikannya membentuk individu yang dapat menyelesaikan diri dalam masyarakat dan memilki tanggung jawab pada masyarakat.

b) Kedudukan peserta didik ialah memperoleh intruksi dan harus menguasai pengetahuan. Disiplin mental dan moral diperlukan dalam setiap jenjang pendidikan.

c) Peran guru adalah menguasai materi, memiliki keterampilan dalam pedagogi untuk mencapai tujuan pendidikan.

d) Kurikulum yang dikembangkan bersifat konfrehensif yaitu memuat semua pengetahuan yang penting. Kurikulum realis menghasilkan pengetahuan yang luas dan praktis.

e) Metode yang dilaksanakan didasari oleh keyakinan bahwa senua pembelajaran tergantung pada pengalaman. Oleh karenanya pengalaman langsung dan bervariasi perlu dilaksanakan oleh peserta didik. Metode penyampaian harus logis dan didukung oleh pengetahuan psikologis. ${ }^{25}$

\section{Pragmatisme}

Pragmatisme biasa juga disebut dengan filsafat praktis atau filasafat aplikasi praktis. Asal mula penanaman filsafat adalah oleh filusuf Amerika Charles, Kata pragmatisme diambil kata pragma (bahasa Yunani) yang berarti tindakan, secara umum pragmatisme hanya idea (pemikiran, pendapat, teori) yang dapat dipraktikan dengan benar dan berguna. ${ }^{26}$

\footnotetext{
${ }^{24}$ Uyoh Saduloh, Pengantar filsafat pendidikan: Alfabeta Publishing:Bandung 2006

$25 \mathrm{https}$ //khasanahilmubinongko.blogspot.com/2015/12/aliran-aliran-filsafat-pendidikan.html

${ }^{26}$ Fuad farid ismail, Berfilsafat Itu Gampang, (Ircisod : Yogyakarta : 2017) hal. 134
} 
Pragmatisme adalah filsafat amerika dengan tokohnya yang terkenal yaitu William James $(1842-1910 \mathrm{M})$

Menurut pragmatisme manusia mampu mencapai bentuk ide (Pemikiran) yang jelas dan efektif khususnya apabila akibat-akibat dari penggunaan suatu ide itu langsung dialami ketika terdapat kesempatan untuk mencoba baik tindakan ide dalam praktek keseharian. Dengan menjadikan pragmatism sebagai filsafat hiduo, tujuan pendidikan ialah agar terwujud pertumbuhan dan perkembangan [ada semua orang, khususnya dengan jalan belajar melalui pengalaman keseharian memecahkan masalah.

Dalam bidang pendidikan, aliran ini berfokus pada penerapan metode berfikir reflektif secara mendasar kedalam kurikulum dan metode mengajar. Sorang guru dari madzhab pragmatic akan menyajikan bahan ajar pelajaran sejarah khususnya sebagai rekam ragam pengalaman manusia dalam mengukur dan mempertimbangkan pengetahuan dan nilai berdasarkan pemahaman tentang kenyataan yang actual.

Paham ini menekankan pentingnya kita melakukan cara cara berfikir dengan baik dan berupaya agar pada siswa tumbuh sikap berfikir kritis agara tak mudah dengan begitu saja menerima suatu sebelum dianggap benar. ${ }^{27}$

\section{Eksistensialisme}

Filsafat eksisitensialisme berkisar pada wujud eksistensi manusia dan segala persoalan hidupnya. ${ }^{28}$ aliran ini menomersatukan hak kebebasan individu menjadi diri sendiriyang bersifat terbuka terhadap segala kemungkinan yang selalu baru.

Disini bagi eksistensialisme, individu bertanggung jawab atas kemauannya yang bebas tanpa memikirkan secara mendalam mana yang benar dan mana yang tidak benar. Sebenarnya, bukannya tidak mengetahui mana yang benar dan mana yang tidak benar, tetapi seorang eksistensialisme dasar bahwa kebenaran bersifat relative, karenanya masing-masing individu bebas menentukan sesuatu yang menurutnya benar.

Inti dari eksistensialisme ialah filsafat hidup yang lebih menghormati hak hidup manusia sebagai individu daripada kebaikan dan nilainya dirusak dan jajah oleh orang laindalam pergaulan hidup. Atas dasar indvidualisme menurut aliran ini tidak ada unsur hakiki dalam alam semesta yang besifat universal. Karena itu tujuan pendidikan ialah

${ }^{27}$ Endang Saefunddin, Ilmu Filsafat Agama, (Imtima : 2007) hal. 23

${ }^{28}$ Fuad farid ismail, Berfilsafat Itu Gampang, (Ircisod : Yogyakarta : 2017) hal. 154 
menumpuk kemampuan individu menjadi diri sendiri yang sebaik baiknya walaupun tak mungkin terbina hubungan urni dalam komunikasi sesama manusia. ${ }^{29}$

Disitulah terjadi pendidikan yang harus dibina seluruh kepribadian manusia seutuhnya, jangan hanya membina akal, ilmu dan teknologi. Manusia memerlukan pembinaan yang positif, begitupula tenta g konsep jati diridan tanggung jawab pribadi. Untuk itu saja sekolah bisa menyediakan semacam stukruktur kurikulum.

1) Pengetahuan.

Teori pengetahuan eksistensialisme banyak dipengaruhi oleh filsafat fenomenologi, suatu pandangan yang menggambarkan penampakan benda-benda dan peristiwa-peristiwa sebagaimana benda-benda tersebut menampakan dirinya terhadap kesadaran manusia. Pengetahuna manusia tergantung kepada pemahamannya tentang realitas, tergantung pada interpretasi manusia terhadap realitas, pengetahuan yang diberikan di sekolah bukan sebagai alat untuk memperoleh pekerjaan atau karir anak, melainkan untuk dapat dijadikan alat perkembangan dan alat pemenuhan diri. Pelajaran di sekolah akan dijadikan alat untuk merealisasikan diri, bukan merupakan suatu disiplin yang kaku dimana anak harus patuh dan tunduk terhadap isi pelajaran tersebut. Biarkanlah pribadi anak berkembang untuk menemukan kebenaran-kebenaran dalam kebenaran.

\section{2) Nilai.}

Pemahaman eksistensialisme terhadap nilai, menekankan kebebasan dalam tindakan. Kebebasan bukan tujuan atau suatu cita-cita dalam dirinya sendiri, melainkan merupakan suatu potensi untuk suatu tindakan. Manusia memiliki kebebasan untuk memilih, namun menentukan pilihan-pilihan di antara pilihan-pilihan yang terbaik adalah yang paling sukar. Berbuat akan menghasilkan akibat, dimana seseorang harus menerima akibat-akibat tersebut sebagai pilihannya. Kebebasan tidak pernah selesai, karena setiap akibat akan melahirkan kebutuhan untuk pilihan berikutnya. Tindakan moral mungkin dilakukan untuk moral itu sendiri, dan mungkin juga untuk suatu tujuan. Seseorang harus berkemampuan untuk menciptakan tujuannya sendiri. Apabila seseorang mengambil tujuan kelompok atau masyarakat, maka ia harus menjadikan tujuan-tujuan tersebut sebagai miliknya, sebagai tujuan sendiri, yang harus ia capai dalam setiap situasi. Jadi, tujuan diperoleh dalam situasi.

\footnotetext{
${ }^{29}$ Endang Saefunddin, Ilmu Filsafat Agama, (Imtima : 2007) hal. 25
} 


\section{3) Pendidikan.}

Eksistensialisme sebagai filsafat sangat menekankan individualitas dan pemenuhan diri secara pribadi. Setiap individu dipandang sebagai makhluk unik, dan secara unik pula ia bertanggung jawab terhadap nasibnya. Dalam hubungannya dengan pendidikan, Sikun Pribadi (1971) mengemukakan bahwa eksistensialisme berhubungan erat sekali dengan pendidikan, karena keduanya bersinggungan satu dengan yang lainnya pada masalah-masalah yang sama, yaitu manusia, hidup, hubungan anatar manusia, hakikat kepribadian, dan kebebasan. Pusat pembicaraan eksistensialisme adalah "keberadaan" manusia, sedangkan pendidikan hanya dilakukan oleh manusia.

\section{4) Tujuan pendidikan.}

Tujuan pendidikan adalah untuk mendorong setiap individu agar mampu mengembangkan semua potensinya untuk pemenuhan diri. Setiap indivudu memiliki kebutuhan dan perhatian yang spesifik berkaitan dengan pemenuhan dirinya, sehingga dalam menentukan kurikulum tidak ada kurikulum yang pasti dan ditentukan berlaku secara umum.

\section{5) Kurikulum.}

Kaum eksistensialisme menilai kurikulum berdasarkan pada apakah hal itu berkontribusi pada pencarian individu akan makna dan muncul dalam suiatu tingkatan kepekaaan personal yang disebut Greene "kebangkitan yang luas". Kurikulum ideal adalah kurikulum yang memberikan para siswa kebebasan individual yang luas dan mensyaratkan mereka untuk mengajukan pertanyaan-pertanyaan, melaksanakan pencarian-pencarian mereka sendiri, dan menarik kesimpulan-kesimpulan mereka sendiri.

\section{6) Peranan guru.}

Menurut pemikiran eksistensialisme, kehidupan tidak bermakna apa-apa, dan alam semesta berlainan dengan situasi yang manusia temukan sendiri di dalamnya. Kendatipun demikian dengan kebebasan yang kita miliki, masing-masing dari kita harus commit sendiri pada penentuan makna bagi kehidupan kita.

\section{PRESPEKTIF FILOSIFIS DALAM PENDIDIKAN ALIRAN UTAMA FILSAFAT PENDIDIKAN}

\section{Peranialisme}


Secara etimologis, perenialisme diambil dari kata perennial dengan mendapattambahan -isme, perenial berasal dari bahasa Latin yaitu perennis, yang kemudian diadopsi ke dalam bahasa Inggris, berarti kekal, selama-lamanya atau abadi. Sedang tambahan -isme di belakang mengandung pengertian aliran atau paham. Filsafat perenial dikatakan juga sebagai filsafat keabadian, sebagaimana dikatakanoleh Frithjof Schuon "philosophi perennis is the universal gnosis wich always has existed and always be exist" (filsafat perenial adalah suatu pengetahuan mistis universal yang telah ada dan akan selalu ada selamanya). ${ }^{30}$

Sebagaimana yang telah dijelaskan sebelumnya, perenialisme merupakan pahamyang menempatkan nilai pada supremasi kebenaran tertinggi yang bersumber pada Tuhan. Dalam membicarakan pendidikan sasaran utama yang akan dicapai adalah "kepemilikan atas prinsipprinsip tentang kenyataan, kebenaran, dan nilai yang abadi, tak terikat waktu dan ruang".

Dengan menempatkan kebenaran supernatural sebagai sumber tertinggi, oleh karena itu perenialisme selalu bersifat theosentris. Karena itu menurut perenialisme, penyadaran nilai dalam pendidikan harus didasarkan pada nilai kebaikan dan kebenaran yang bersumber dari wahyu dan hal itu dilakukan melalui proses penanaman nilai pada peserta didik.20 Sedang kebenaran hakiki dapat diperoleh dengan latihan intelektual secara cermat untuk melatih kemampuan pikir dan latihan karakter untuk mengembangkan kemampuan spiritual.

Tujuan dari pendidikan, menurut pemikiran perennialis, adalah memastikan bahwa para siswa memperoleh pengetahuan tentang prinsip - prinsip atau gagasan - gagasan besar yang tidak berubah.

Tuntutan tertinggi dalam belajar, menurut perenialisme adalah latihan dan disiplin mental. Maka teori dan praktek pendidikan haruslah mengarah kepada tuntutan tersebut. Manusia sebagai makhluk yang memiliki sifat rasional dan sifat itulah yang melahirkan konsep dasar tentang kebebasan. Manusia memiliki senjata yang bersifat rasional tersebut untuk dapat menghilangkan belenggu atau rintangan yang dihadapi dan menjadi merdeka. Kemerdekaan itu haruslah menjadi tujuan dan dilaksanakan dalam pendidikan, supaya anak didik mempunyai kemampuan untuk berbuat dengan sengaja. Atas dasar pandangan tersebut dapat disimpulkan bahwa belajar itu pada hakekatnya adalah belajar untuk berpikir. ${ }^{31}$ Kurikulum menurut kaum perenialis harus menekankan pertumbuhan intelektual siswa pada seni dan

30 M.Arfan Mu'ammar, PERENIALISME PENDIDIKAN (Analisis Konsep Filsafat Perenial dan Aplikasinya dalam Pendidikan Islam) Nur EI-Islam, Volume 1, Nomor 2, Oktober 2014. Hal. 15

${ }^{31} \mathrm{https}$ ://www.academia.edu/8946247/Makalah_Filsafat_Pendidikan_Aliran_Perenialisme_Dalam_Fils afat_Pendidikan_ALIRAN_PERENIALISME_DALAM_FILSAFAT_PENDIDIKAN 
sains, bidang - bidang yang merupakan karya terbaik dan paling signifikan yang diciptakan oleh manusia untuk dapat menjadi "terpelajar secara kultural".

\section{Esensialisme}

Esinsialisme berasal dari kata essence, artinya esensi atau inti, dirilis oleh WC Bagley, esensial menyiapkan siswa menjadi warga yang efektif dalam berdemokrasi. ${ }^{32}$

Kaum esensialis yakin ada beberapa keahlian yang memberikan kontribusi terhadap kebaikan manusia, di antaranya membaca, menulis, dan berhitung, serta tindakan sosial yang rasional. Kompetensi tersebut merupakan elemen yang sangat baik dan dibutuhkan dalam kurikulum pendidikan pada jenjang pendidikan dasar. Sementara pada jenjang pendidikan menengah kurikulum terdiri dari sejarah, matematika, sains, bahasa, dan sastra. Setelah menuntaskan pelajaran tersebut, maka siswa diharapkan dapat menyesuaikan diri dengan lingkungan alam dan lingkungan sosial. Pendidikan merupakan persiapan bagi warga masyarakat yang beradab. Sementara itu, disiplin, keterampilan, seni dan sains memerlukan pengaturan yang tepat. Oleh karena itu, bagi esensialis diperlukan guru yang dewasa, memahamai pelajaran, dan mampu menstranformasikan pengetahuan dan nilai-nilai kebaikan kepada siswa.

Salah seorang tokoh esensialis dari Amerika Serikat adalah Robert Ulich. Ia mengatakan bahwa kurikulum dapat saja fleksibel, tetapi tidak untuk pemahaman mengenai agama dan alam semesta. Oleh karena itu, perlu perencanaan kurikulum dengan seksama. Sementara Butler mengatakan bahwa anak perlu dididik untuk mengetahui dan mengagumi kitab suci (Injil), sedangkan Demihkevich mengatakan bahwa kurikulum harus berisikan moralitas yang tinggi.

Prinsip-prinsip aliran Essensialisme dalam pendidikan ialah tugas pertama sekolah adalah mengajarkan pengetahuan dasariah, belajar adalah usaha keras dan menuntut kedisiplinan, dan guru adalah lokus otoritas ruang kelas.

\section{Progresivisme}

Progresivisme artinya (progress, artinya kemajuan) dirilis oleh FW Parker sebagai gerakan reformasi pasca peranh sipil menjelang abad 19, kemudian direvisi oleh Jhon Dewey. Dewey menemukan progresivisme dengan penekanan bahwa ide harus selalu diukur dengan eksperimen. ${ }^{33}$

${ }^{32}$ Tim Kurikulum, Ilmu dan Aplikasi Pendidikan, (Imtima : Yogayakarta 2007) hal. 26

${ }^{33}$ Tim Kurikulum, Ilmu dan Aplikasi Pendidikan, (Imtima : Yogayakarta 2007) hal. 262 
Aliran progresivisme lahir di Amerika Serikat sekitar tahun 1870. Para reformis yang menamakan diri kaum progressive menentang sistem pendidikan tradisional yang sangat kaku, menuntut disiplin ketat, dan membuat peserta didik menjadi pasif. Gerakan pembaharuan yang sudah ada sejak akhir abad 19 itu mendapatkan angin baru pada abad 20 dengan munculnya aliran filsafat Pragmatisme. John Dewey berusaha menjalin pendidikan progresif dengan filsafat Pragmatisme (Sudarminta, 1994: 44). Selaras dengan pandangan kaum Pragmatis yang menyatakan bahwa realitas itu terus menerus berubah. Pendidikan bagi kaum progressive merupakan proses penggalian pengalaman terus-menerus. Pendidikan haruslah senantiasa siap sedia mengubah metode dan kebijakan perencanaan pembelajaran yang dapat mengikuti perkembangan ilmu pengetahuan dan perubahan lingkungan. Inti pendidikan tidak terletak dalam usaha penyesuaian dengan masyarakat atau dunia luar sekolah, dan juga tidak terletak dalam usaha untuk menyesuaikan dengan standar kebaikan, kebenaran, dan keindahan yang abadi. Akan tetapi pendidikan merupakan usaha terus menerus merekostruksi (menyusun ulang) pengalaman hidup.

Pendidikan merupakan tafsiran terhadap rangkaian pengalaman sedemikian rupa sehingga seseorang dapat mengertinya dengan lebih jelas dan dalam perspektif yang lebih benar. Bertambahnya pengalaman bermakna tentang masa lalu dan masa sekarang memungkinkan seseorang untuk lebih tepat mengarahkan diri pada jalan menuju pengalaman mendatang, sehingga seseorang tidak hanya mengikuti arus, tetapi dapat menentukan jalannya sejarah. Pengalaman memiliki makna substansial dalam pengalaman belajar. Pengalaman yang dimaksud tidak sembarang pengalaman, tetapi sebuah pengalaman bermakna yang dialami oleh seseorang. ${ }^{34}$

John Dewey sebagai bapak progresivisme mengatakan bahwa pendidikan dipandang sebagai proses dan sosialisasi, yaitu proses pertumbuhan dan proses belajar dari kejadian di sekitarnya (gutek, 1988: 85). Oleh karena itu, dinding pemisah antara sekolah dan masyarakat perlu dihapuskan, sebab belajar yang baik tidak cukup di sekolah saja. Sekolah yang ideal adalah sekolah yang isi pendidikannya berintegrasi dengan lingkungan sekitar.

\section{Rekonstruksionisme}

Rekonstruksionisme merupakan kelanjutan dari gerakan progresivisme. Gerakan ini lahir didasarkan atas suatu anggapan bahwa kaum progresif hanya memikirkan dan Hal. 50

\footnotetext{
${ }^{34}$ Rukuyati dan andriani, Mengenal Filsafat Pendidikan, Draf Buku Universitas Negri Yogyakarta,
} 
melibatkan diri dengan masalah-masalah masyarakat yang ada sekarang. Rekonstruksionisme ingin membangun masyarakat baru masyarakat yang pantas dan adil.

Aliran rekonstruksionisme adalah suatu aliran yang berusaha merombak tata susunan lama dan membangun tata susunan hidup kebudayaan yang bercorak modern. ${ }^{35}$

Pandangan kaum rekonstruksionisme termasuk ke dalam kelompok progressif yang sasarannya lebih luas. Berikut ini pokok-pokok pemikiran rekonstruksionisme terkait dengan dunia, masyarakat, dan pendidikan.

Rekonstruksionisme sosial secara mencolok bersifat kontras dengan kaum konservatif . Rekonstruksionisme menganggap bahwa dunia dan moral manusia mengalami degradasi di sana-sini sehingga perlu adanya rekonstruksi tatanan sosial menuju kehidupan yang demokratis, emansipatoris dan seimbang. Keadaan yang timpang dan hanya menguntungkan salah satu belahan dunia harus diatasi dengan merekonstruksi pendidikan untuk memajukan peradaban. Kaum rekonstruksionis percaya bahwa dengan pendidikan yang baik, maka moral manusia dapat pula menjadi baik. Pendidikan yang mengedepankan kepekaan sosial dan perjuangan HAM mendapat penekanan. Kaum rekonstruksionis meyakini bahwa masyarakat modern dan daya tahan manusia modern saling berkaitan erat. Untuk menjamin keberlangsungan hidup manusia dan untuk menciptakan peradaban yang lebih memuaskan, manusia harus menjadi insinyur sosial, yaitu orang yang mampu merancang jalannya perubahan dan mengarahkan ilmu pengetahuan dan teknologi secara dinamis untuk mencapai tujuan yang diinginkan. Kaum rekonstruksionis percaya bahwa semua reformasi sosial muncul dalam kehidupan itu sendiri.

Pendidikan adalah jalan utama untuk perubahan atau reformasi sosial. Pendidikan berperan untuk memelihara: (1) kepekaan akan adanya diskriminasi dalam pewarisan budaya; (2) berkomitmen untuk bekerja bagi upaya reformasi sosial yang adil.; (3) kehendak untuk mengembangkan mentalitas yang terencana yang mampu mengarahkan jalannya revisi budaya; (4) pengujian rencana budaya yang telah dilaksanakan dalam berbagai program untuk mewujudkan reformasi social. ${ }^{36}$

\section{PRESPEKTIF FILOSIFIS DALAM PENDIDIKAN DARI TEORI BELAJAR UTAMA}

\section{6) hal. 237}

${ }^{35}$ Muhammad Kristiawan, Filsafat Pendidikan, The Choice Is Yours, (Yogyakarta : Valia Pustaka : Hal. 57

${ }^{36}$ Rukuyati dan andriani, Mengenal Filsafat Pendidikan, Draf Buku Universitas Negri Yogyakarta, 
Ada tiga kategori utama atau kerangka filosofis mengenai teori-teori belajar, yaitu: teori belajar behaviorisme, teori belajar kognitivisme, dan teori belajar konstruktivisme. Teori belajar behaviorisme hanya berfokus pada aspek objektif diamati pembelajaran. Teori kognitif melihat melampaui perilaku untuk menjelaskan pembelajaran berbasis otak. Dan pandangan konstruktivisme belajar sebagai sebuah proses di mana pelajar aktif membangun atau membangun ide-ide baru atau konsep.

\section{Teori belajar Behaviorisme}

Teori behavioristik adalah sebuah teori yang dicetuskan oleh Gage dan Berliner tentang perubahan tingkah laku sebagai hasil dari pengalaman. Teori ini lalu berkembang menjadi aliran psikologi belajar yang berpengaruh terhadap arah pengembangan teori dan praktik pendidikan dan pembelajaran yang dikenal sebagai aliran behavioristik. Aliran ini menekankan pada terbentuknya perilaku yang tampak sebagai hasil belajar.

Teori behavioristik dengan model hubungan stimulus-responnya, mendudukkan orang yang belajar sebagai individu yang pasif. Respon atau perilaku tertentu dengan menggunakan metode pelatihan atau pembiasaan semata. Munculnya perilaku akan semakin kuat bila diberikan penguatan dan akan menghilang bila dikenai hukuman.

\section{Teori Belajar kognitivisme}

Teori belajar kognitif mulai berkembang pada abad terakhir sebagai protes terhadap teori perilaku yang yang telah berkembang sebelumnya. Model kognitif ini memiliki perspektif bahwa para peserta didik memproses infromasi dan pelajaran melalui upayanya mengorganisir, menyimpan, dan kemudian menemukan hubungan antara pengetahuan yang baru dengan pengetahuan yang telah ada. Model ini menekankan pada bagaimana informasi diproses.

Peneliti yang mengembangkan teori kognitif ini adalah Ausubel, Bruner, dan Gagne. Dari ketiga peneliti ini, masing-masing memiliki penekanan yang berbeda. Ausubel menekankan pada apsek pengelolaan (organizer) yang memiliki pengaruh utama terhadap belajar.Bruner bekerja pada pengelompokkan atau penyediaan bentuk konsep sebagai suatu jawaban atas bagaimana peserta didik memperoleh informasi dari lingkungan. 


\section{Teori Belajar Konstruktivisme}

Kontruksi berarti bersifat membangun, dalam konteks filsafat pendidikan dapat diartikan Konstruktivisme adalah suatu upaya membangun tata susunan hidup yang berbudaya modern.

Konstruktivisme merupakan landasan berfikir (filosofi) pembelajaran konstektual yaitu bahwa pengetahuan dibangun oleh manusia sedikit demi sedikit, yang hasilnya diperluas melalui konteks yang terbatas dan tidak sekonyong-konyong.

Pengetahuan bukanlah seperangkat fakta-fakta, konsep, atau kaidah yang siap untuk diambil dan diingat. Manusia harus mengkontruksi pengetahuan itu dan memberi makna melalui pengalaman nyata.

Dengan teori konstruktivisme siswa dapat berfikir untuk menyelesaikan masalah, mencari idea dan membuat keputusan. Siswa akan lebih paham karena mereka terlibat langsung dalam mebina pengetahuan baru, mereka akan lebih pahamdan mampu mengapliklasikannya dalam semua situasi. Selian itu siswa terlibat secara langsung dengan aktif, mereka akan ingat lebih lama semua konsep.

\section{Teori Humanisme}

Pada dasarnya, teori humanistik adalah teori belajar yang memanusiakan manusia. Pembelajaran dipusatkan pada pribadi seseorang. Teori ini tidak lepas dari pendidikan yang berfokus pada bagaimana menghasilkan sesuatu yang efektif, bagaimana belajar yang bisa meningkatkan kreativitas dan memanfaatkan potensi yang ada pada seseorang. Teori humanistik ini muncul sebagai perlawanan terhadap teori belajar sebelumnya, yaitu Teori Behaviouristik, yang dianggap terlalu kaku, pasif, bahkan penurut ketika menggambarkan manusia.

Dalam pengertian teori humanistik, proses pembelajaran cenderung lebih abstrak. Bidang kajian yang mendekati teori ini adalah Filsafat, Teori Kepribadian, dan Psikoterapi. Teori ini lebih condong untuk mementingkan konten pembelajaran dibandingkan bagaimana proses belajar berjalan. Keberhasilan suatu pembelajaran menurut teori ini adalah ketika ada keinginan dari dalam diri seseorang untuk belajar, mengetahui informasi baru, sehingga terjadi asimilasi dalam struktur kognitinya. 
Teori belajar humanistik paling dekat untuk digunakan oleh guru. Guru merupakan profesi yang bisa berperan sebagai fasilitator dalam proses belajar seseorang. Teori ini merupakan panduan atau guideness yang bisa digunakan untuk mendampingi murid selaku peserta belajar agar mereka bisa mendalami proses belajar tersebut dari dalam dirinya sendiri. $^{37}$

\section{KESIMPULAN}

\section{A. KESIMPULAN}

Dalam filsafat terdapat berbagai mazhab/ aliran-aliran, seperti materialisme, idealisme, realisme, pragmatisme, dan lainlain. Karena filsafat pendidikan merupakan terapan dari filsafat, sedangkan filsafat beraneka ragam alirannya, maka setiap dari aliran-aliran, cabangcabang filsafat memiliki prespektifnya masing- masing dalam Pendidikan.

1. Ontologi dalam kajian ini lebih menekankan pada aspek hakikat keberadaan, yang dimaksud keberadaan di sini adalah keberadaan pendidikan. Sedangkan hakikat pendidikan berkaitan dengan hakikat manusia. Dari pemahaman tersebut, sudah tentu hakikat pendidikan atau ontologi pendidikan berakar dari kebutuhan hidup manusia berkenaan dengan proses berpikir, berkemandirian dalam berbagai macam hal baik dalam kemandirian berpikir

2. Dalam pandangan Aksiologi Pendidikan dapat diartikan dengan kegiatan mengubah manusia sehingga mengembangkan hakikat kemanusiaan. Kegiatan pendidikan dilakukan dari oleh dan untuk manusia yang bertujuan mengembangkan potensi kemanusiaan. Langeveld (seorang Paedagog Belanda) mengemukakan hasil analisis epistemologis dengan metode fenomenologis bahwa manusia adalah animal educandum, educabile dan educans. Epistemologi diperlukan dalam menyusun kurikulum. Kurikulum lazimnya diartikan sebagai sarana untuk mencapai tujuan pendidikan

3. Implikasi aksiologi dalam dunia pendidikan adalah menguji dan mengintegrasikan nilai dalam kehidupan manusia dan menanamkan sikap dalam kepribadian peserta didik, dan . Pendidikan harus memberikan pemahaman atau pengertian baik, benar, bagus, buruk dan sejenisnya kepada peserta didik secara komprehensif dalam arti dilihat dari segi etika, estetika dan nilai social

\footnotetext{
${ }^{37}$ https://dosenpsikologi.com/teori-belajar-humanistik
} 
4. Pendidikan harus menekankan kesesuian batin antara anak dan alam semesta. Pendidikan merupakan pertumbuhan ke arah tujuan pribadi manusia yang ideal. Pendidik yang idealisme mewujudkan sedapat mungkin watak yang terbaik. Pendidik harus memandang anak sebagai tujuan, bukan sebagai alat

5. Dalam bidang pendidikan aliran realism berfokus pada tujuan pendidikan untuk membina kemampuan manusia melakukan interaksi yang konstruktif dalam hubungan manusia sebagai warga masyarakat dan melakukan penyesuaian diri dengan mengelola tanpa terlalu mengekploitasi alam. Pendidikan harus dilakukan dengan cara cara membantu siswa dan anak untuk memamhami dan menerima hukum hokum alam dan kehidupan apa adanya karena hokum kuhum menekan manusia sebagai hokum alam

6. Dalam bidang pendidikan, aliran paranilaisme berfokus pada penerapan metode berfikir reflektif secara mendasar kedalam kurikulum dan metode mengajar.

7. Dalam prespektif eksistensialisme, pendidikan yang harus dibina seluruh kepribadian manusia seutuhnya, jangan hanya membina akal, ilmu dan teknologi. Manusia memerlukan pembinaan yang positif, begitupula tenta g konsep jati diridan tanggung jawab pribadi. Untuk itu saja sekolah bisa menyediakan semacam stukruktur kurikulum.

8. Tujuan dari pendidikan, menurut pemikiran perennialis, adalah memastikan bahwa para siswa memperoleh pengetahuan tentang prinsip - prinsip atau gagasan - gagasan besar yang tidak berubah.

9. Prinsip-prinsip aliran Essensialisme dalam pendidikan ialah tugas pertama sekolah adalah mengajarkan pengetahuan dasariah, belajar adalah usaha keras dan menuntut kedisiplinan, dan guru adalah lokus otoritas ruang kelas

10. Pendidikan meneurut progresivisme haruslah senantiasa siap sedia mengubah metode dan kebijakan perencanaan pembelajaran yang dapat mengikuti perkembangan ilmu pengetahuan dan perubahan lingkungan.

11. Pendidikan meneurut rekonstruksionisme adalah jalan utama untuk perubahan atau reformasi sosial.

12. Teori behavioristik dengan model hubungan stimulus-responnya, mendudukkan orang yang belajar sebagai individu yang pasif. Sedangkan perspektif teori belajar kognitiv bahwa para peserta didik memproses infromasi dan pelajaran melalui upayanya mengorganisir, menyimpan, dan kemudian menemukan hubungan antara pengetahuan 
yang baru dengan pengetahuan yang telah ada. Dalam teori Konstruktivisme merupakan landasan berfikir (filosofi) pembelajaran konstektual yaitu bahwa pengetahuan dibangun oleh manusia sedikit demi sedikit, yang hasilnya diperluas melalui konteks yang terbatas dan tidak sekonyong-konyong . lalu Teori belajar humanistik paling dekat untuk digunakan oleh guru. Guru merupakan profesi yang bisa berperan sebagai fasilitator dalam proses belajar seseorang

\section{DAFTAR PUSTAKA}

A. Susanto, 2011. Filsafat Ilmu: Suatu Kajian dalam Dimensi Ontologi, Epistemologis, dan Aksiologis , Jakarta: Bumi Aksara.

Ahmad Tafsir, 2016. Filsafat Umum, Bandung : Rosda

Anas Salahuddin, 2011. Filsafat Pendidikan, Bandung: Pustaka Setia.

Aziz, A., \& Saihu, S. (2019). Interpretasi Humanistik Kebahasaan: Upaya Kontekstualisasi Kaidah Bahasa Arab. Arabiyatuna: Jurnal Bahasa Arab, 3(2), 299-214

Endang Saefunddin, 2007. Ilmu Filsafat Agama, Imtima : Yogyakarta.

Fuad farid ismail, 2017. Berfilsafat Itu Gampang, Ircisod : Yogyakarta.

http://kuliah-e-learning.blogspot.com/2013/11/filsafat-idealisme-dalam-

pendidikan.html

https://dosenpsikologi.com/teori-belajar-humanistik

https://khasanahilmubinongko.blogspot.com/2015/12/aliran-aliran-filsafat-

pendidikan.html

https://www.academia.edu/8946247/Makalah_Filsafat_Pendidikan_Aliran_Perenialism

e_Dalam_Filsafat_Pendidikan_ALIRAN_PERENIALISME_DALAM_FILSA

FAT_PENDIDIKAN

M.Arfan Mu'ammar, 2, Oktober 2014. PERENIALISME PENDIDIKAN (Analisis Konsep Filsafat Perenial dan Aplikasinya dalam Pendidikan Islam) Nur ElIslam, Volume 1.

Mahfud, MENGENAL ONTOLOGI, EPISTEMOLOGI, AKSIOLOGI DALAM PENDIDIKAN ISLAM (STAI : Hasan Jufri Bawean)

Mohammad Adib, 2011. Filsafat Ilmu: Ontologi, Epistemologi, Aksiologi, dan Logika Ilmu Pengetahuan Yogyakarta: Pustaka Pelajar.

Mubin, F. (2019). TAFSIR EMANSIPATORIS: PEMBUMIAN METODOLOGI TAFSIR PEMBEBASAN. Mumtaz: Jurnal Studi Al-Quran dan Keislaman, 3(1), 131-151. 
Mubin, F. KEADILAN DALAM GENDER: KAJIAN KEPEMIMPINAN WANITA DALAM ISLAM1,

Mubin, F. MODEL-MODEL PEMBELAJARAN BERBASIS MADRASAH DAN KEGIATAN LAIN YANG DIPERLUKAN DI DALAMNYA (FAKTOR PENDUKUNGNYA).

Muhammad Kristiawan, 2016. Filsafat Pendidikan, The Choice Is Yours, (Yogyakarta :

Valia Pustaka

Ronaldo, R., Zulfikar, A., Saihu, Ismail, \& Wekke, I. S. (2020). International relations of the asia pacific in the age of trump. Journal of Environmental Treatment Techniques, 8(1), 244-246.

Rukuyati dan andriani, 2016. Mengenal Filsafat Pendidikan, Draf Buku Universitas

Negri Yogyakarta, hal. 1

Rukuyati dan andriani, Mengenal Filsafat Pendidikan, Draf Buku Universitas Negri

Yogyakarta, Hal. 50

Şahin, C. RELIGIA.

Saihu, Aziz, A., Mubin, F., \& Sarnoto, A. Z. (2020). Design of islamic education based on local wisdom (An analysis of social learning theories in forming character through ngejot tradition in bali). International Journal of Advanced Science and Technology, 29(6), 1278-1293.

Saihu, M. (2019). Urgensi 'Urf dalam Tradisi Male dan Relevansinya dalam Dakwah Islam di Jembrana-Bali. Jurnal Bimas Islam, 12(1), 173-201.

Saihu, M. (2019). Merawat Pluralisme Merawat Indonesia (Potret Pendidikan Pluralisme Agama Di Jembrana-Bali). Deepublish.

Saihu, M. M., \& Aziz, A. (2020). Implementasi Metode Pendidikan Pluralisme Dalam Mata Pelajaran Pendidikan Agama Islam. Belajea; Jurnal Pendidikan Islam, 5(1), 131-150.

Saihu, S. (2019). IMPLEMENTASI MANAJEMEN BALANCED SCORECARD DI PONDOK PESANTREN JAM'IYYAH ISLAMIYYAH TANGERANG SELATAN. Mumtaz: Jurnal Studi Al-Quran dan Keislaman, 3(1), 1-22.

Saihu, S. (2019). KOMUNIKASI PENDIDIK TERHADAP ANAK BERKEBUTUHAN KHUSUS DI SEKOLAH KHUSUS ASY-SYIFA LARANGAN. Andragogi: Jurnal Pendidikan Islam dan Manajemen Pendidikan Islam, 1(3), 418-440.

Saihu, S. (2019). KONSEP MANUSIA DAN IMPLEMENTASINYA DALAM PERUMUSAN TUJUAN PENDIDIKAN ISLAM MENURUT MURTADHA MUTHAHHARI. Andragogi: Jurnal Pendidikan Islam dan Manajemen Pendidikan Islam, 1(2), 197-217.

Saihu, S. (2019). PENDIDIKAN KARAKTER BERBASIS KEARIFAN LOKAL (STUDI DI JEMBRANA BALI). Edukasi Islami: Jurnal Pendidikan Islam, 8(01), 69-90.

Saihu, S. (2019). Pendidikan Pluralisme Agama: Kajian tentang Integrasi Budaya dan Agama dalam Menyelesaikan Konflik Sosial Kontemporer. Jurnal Indo-Islamika, 9(1), $67-90$,

Saihu, S. (2019). RINTISAN PERADABAN PROFETIK UMAT MANUSIA MELALUI PERISTIWA TURUNNYA ADAM AS KE-DUNIA. Mumtaz: Jurnal Studi Al-Quran dan Keislaman, 3(2), 268-279,

Saihu, S. (2020). ETIKA MENUNTUT ILMU MENURUT KITAB TA'LIM MUTA’ALIM. Al Amin: Jurnal Kajian Ilmu dan Budaya Islam, 3(1), 99-112. 
Saihu, S. (2020). KONSEP PEMBAHARUAN PENDIDIKAN ISLAM MENURUT FAZLURRAHMAN. Andragogi: Jurnal Pendidikan Islam dan Manajemen Pendidikan Islam, 2(1), 82-95.

Saihu, S. (2020). Pendidikan sosial yang terkandung dalam Surat At-Taubah Ayat 7172. Edukasi Islami: Jurnal Pendidikan Islam, 9(01), 127-148.

Saihu, S. (2020). The Effect of Using Talking Stick Learning Model on Student Learning Outcomes in Islamic Primary School of Jamiatul Khair, Ciledug Tangerang. Tarbawi: Jurnal Keilmuan Manajemen Pendidikan, 6(01), 61-68.

Saihu, S., \& Mailana, A. (2019). Teori pendidikan behavioristik pembentukan karakter masyarakat muslim dalam tradisi Ngejot di Bali. Ta'dibuna: Jurnal Pendidikan Islam, 8(2), 163-176.

Saihu, S., \& Marsiti, M. (2019). PENDIDIKAN KARAKTER DALAM UPAYA MENANGKAL RADIKALISME DI SMA NEGERI 3 KOTA DEPOK, JAWA BARAT. Andragogi: Jurnal Pendidikan Islam dan Manajemen Pendidikan Islam, 1(1), 23-54.

Saihu, S., \& Rohman, B. (2019). PEMBENTUKAN KARAKTER MELALUI MODEL PENDIDIKAN TRANSFROMATIFE LEARNING PADA SANTRI DI PONDOK PESANTREN NURUL IKHLAS BALI. Edukasi Islami: Jurnal Pendidikan Islam, 8(02), 435-452.

Saihu, S., \& Taufik, T. (2019). PERLINDUNGAN HUKUM BAGI GURU. Al Amin: Jurnal Kajian Ilmu dan Budaya Islam, 2(2), 105-116.

Tim Kurikulum, 2007. Ilmu dan Aplikasi Pendidikan, Imtima : Yogayakarta

Tim Penyusun, 2011. Pengantar Filsafat, Surabaya: IAIN Sunan Ampel Press

Uyoh Saduloh, 2006. Pengantar filsafat pendidikan: Alfabeta Publishing:Bandung 